\title{
Kinetics of water sorption of damaged bean grains: Thermodynamic properties
}

\author{
Paulo C. Corrêa ${ }^{1}$, Fernanda M. Baptestini ${ }^{2}$, Jaime D. B. Vanegas ${ }^{3}$, \\ Rafael Leite ${ }^{3}$, Fernando M. Botelho ${ }^{4}$ \& Gabriel H. H. de Oliveira ${ }^{5}$ \\ ${ }^{1}$ Universidade Federal de Viçosa/Departamento de Engenharia Agrícola e Ambiental. Viçosa, MG. E-mail: copace@ufv.br \\ ${ }^{2}$ Universidade Federal do Espírito Santo/Departamento de Engenharia Rural. Alegre, ES. E-mail: fbaptestini@yahoo.com.br (Corresponding author) \\ ${ }^{3}$ Universidade Federal de Viçosa/Departamento de Engenharia Agrícola. Viçosa, MG. E-mail: jdbustosv@gmail.com; ufvrafael@yahoo.com.br \\ ${ }^{4}$ Universidade Federal de Mato Grosso/Instituto de Ciências Agrárias e Ambientais. Sinop, MT. E-mail: fernando_eaa@yahoo.com.br \\ ${ }^{5}$ Instituto Federal de Educação, Ciência e Tecnologia Sudeste de Minas Gerais. Manhuaçu, MG. E-mail: gabriel.oliveira@ifsudestemg.edu.br
}

Key words:

enthalpy

entropy

Gibbs free energy

\begin{abstract}
A B S T R A C T
This study aims to determine the thermodynamic properties of damaged beans. Grains with initial moisture content of $53.85 \%$ (d.b.) were used. A part of the grains was used to obtain the desorption isotherms, while another part was subjected to drying until a moisture content of $5.26 \%$ (d.b.) was achieved; therefore, it was subjected to the adsorption process. To induce damage, a Stein breakage tester was used. To obtain the equilibrium moisture content, grains were placed in a climatic chamber whose temperatures were $20,30,40$, and $50 \pm 1{ }^{\circ} \mathrm{C}$ combined with a relative humidity of $30,40,50,70$, and $90 \pm 3 \%$. Although in the desorption process, damaged grains had a lower differential enthalpy compared with the control, the reverse behavior was observed in the adsorption process. Mechanical damage caused the formation of a greater number of available adsorption sites, resulting in higher differential entropy values in adsorption and lower values in desorption compared with the control. The mechanical damage had no effect on the Gibbs free energy.
\end{abstract}

\section{Palavras-chave:}

entalpia

entropia

energia livre de Gibbs

\section{Cinética de sorção de água de grãos de feijão danificado: Propriedades termodinâmicas}

\section{R E S U M O}

Objetivou-se determinar as propriedades termodinâmicas de grãos de feijão danificados. Foram utilizados grãos com teor de água inicial de 53,85\% (b.s.); parte dos grãos foi utilizada para se obter as isotermas de dessorção, enquanto que a outra foi submetida a secagem até o teor de água de 5,26\% (b.s.), para que a mesma fosse submetida ao processo de adsorção. Para a indução da danificação foi utilizado um Stein Breakage Tester. Para obter o teor de água de equilíbrio, os grãos foram colocados em câmara climática cujas temperaturas foram de 20, 30, 40 e $50 \pm 1{ }^{\circ} \mathrm{C}$ combinadas com umidades relativas de 30, 40, 50, 70 e $90 \pm 3 \%$. Na dessorção, os grãos danificados apresentaram menor entalpia diferencial quando comparados com a testemunha enquanto o inverso foi observado na adsorção. A danificação mecânica provocou a formação de um número maior de sítios disponíveis de sorção, resultando em maiores valores de entropia diferencial na adsorção e menores valores na dessorção quando comparados com a testemunha. A danificação mecânica não teve efeito sobre a energia livre de Gibbs. 


\section{INTRODUCTION}

The Fabaceae are a source of energy and nutrients in the human diet, and among the species belonging to this group, the genus Phaseolus bean has the greatest economic importance (Ron et al., 1999). Besides being of great socio-economic importance in Brazil, it is the main source of protein in the diet of most Brazilians, followed in importance by beef and rice. These three basic foods contribute approximately $70 \%$ of the protein intake (Machado et al., 2008). In addition, beans are extremely important owing to its low cost compared to animal products, both source of protein (Mesquita et al., 2007).

The cleaning, separation, and drying are the major postharvest operations for the grains (Angelovič et al., 2013). Product movement and hence some kind of mechanical damage is inherent during handling, which in many cases is so severe that it leads to the death of the embryo. In addition, impacts, abrasions, cuts, or pressures can sometimes occur, resulting in invisible damage.

According to Oliveira et al. (2014), the study of the thermodynamics in the drying processes of agricultural products is important for projection and equipment sizing in several processes of quality preservation. Furthermore, thermodynamic properties aid the understanding of moisture movement that occur within the product during a post-harvest operation such as drying.

Some thermodynamic properties are used to analyze the sorption behavior in biological systems, including differential enthalpy and entropy and the theory of compensation, which are calculated from sorption isotherms (Thys et al., 2010).

There are countless studies that investigated the thermodynamic properties of agricultural products (Moreira et al., 2008; Oliveira et al., 2011; Goneli et al., 2013; Corrêa et al., 2015; Ascheri \& Bastos, 2015); however, studies focusing on the mechanical damage in beans are scarce. Based on this, the objective of this study is to investigate the alterations in thermodynamic properties (integral isosteric heat of sorption, differential entropy, Gibbs free energy, and enthalpy-entropy compensation theory) of drying and sorption processes due to controlled damage, which approximates to the practical conditions at the production site and industry.

\section{Material AND Methods}

Beans of the red group (Phaseolus vulgaris L.) from the experimental field of Phytotechny Department of the Federal University of Viçosa were used. They had an initial moisture content of $53.85 \%$ (d.b.); then, they were harvested and threshed by hand to avoid any mechanical damage to the grains.

A part of these grains was used to obtain the desorption isotherms, while another part was subjected to drying at a controlled temperature of $40{ }^{\circ} \mathrm{C}$ until a moisture content of $5.26 \%$ (d.b.) was achieved after drying for approximately $7 \mathrm{~h}$. The samples at $5.26 \%$ (d.b.) were subsequently subjected to adsorption process.

The product moisture content was determined by the gravimetric method in three repetitions at $105 \pm 1{ }^{\circ} \mathrm{C}$ for 24 h (Brasil, 2009).
In order to induce mechanical damage, a Stein breakage tester Model M-CK2 was used. This device has a steel cylinder and a central propeller that spins at a constant speed of 1800 rpm, thereby promoting impact between grain and cylinder wall and between grain and grain.

Part of the samples for adsorption and desorption were subjected to mechanical damage for 4 min (damaged sample) and the rest were kept intact (control sample).

The level of damage to the product was evaluated indirectly by the electrical conductivity of the solution of exudates of the beans using a portable Digimed model DM3 conductivity meter. For this test, fifty-five subsamples of the grains from each treatment (with and without damage) were counted and weighed. Samples were placed in plastic cups with $75 \mathrm{~mL}$ of deionized water and maintained in a temperature-controlled chamber at $25^{\circ} \mathrm{C}$ for $24 \mathrm{~h}$ (Santos et al., 2011). The bean samples subjected to induced mechanical damage showed an average electrical conductivity of exudates of the grain of $152.38 \mu \mathrm{S}$ $\mathrm{cm}^{-1} \mathrm{~g}^{-1}$, while the control sample showed an average of 29.88 $\mu \mathrm{S} \mathrm{cm} \mathrm{cm}^{-1} \mathrm{~g}^{-1}$.

In order to obtain the equilibrium moisture content of the dynamic method (Goneli et al., 2010), the beans were placed in a climate chamber (brand New Ethics, model 420/CLD-150). The temperatures used were $20,30,40$, and $50 \pm 1^{\circ} \mathrm{C}$ combined with relative moistures of $30,40,50,70$, and $90 \pm 3 \%$. For each environment condition, three replications were carried out.

In a previous study by the same research group (Baptestini et al., 2017), it was found that the Guggenheim-Anderson-de Boer (GAB) model satisfactorily described the equilibrium moisture content of the damaged beans at the same conditions used in the present study. Therefore, water activity was calculated using the GAB model, which is required to obtain the thermodynamic properties as described below.

Thermodynamic properties of damaged beans of water sorption and control process were obtained by the method described by Corrêa et al. (2012) as expressed by Eqs. 1-5.

$$
\begin{gathered}
\operatorname{lna}_{\mathrm{w}}= \pm\left(\frac{\Delta \mathrm{h}_{\mathrm{st}}}{\mathrm{RT}_{\mathrm{a}}}-\frac{\Delta \mathrm{S}}{\mathrm{R}}\right) \\
\mathrm{Q}_{\mathrm{st}}=\Delta \mathrm{h}_{\mathrm{st}}+\mathrm{L} \\
\Delta \mathrm{G}= \pm \mathrm{RT}_{\mathrm{a}} \operatorname{lna}_{\mathrm{w}} \\
\mathrm{T}_{\mathrm{hm}}=\frac{\mathrm{n}}{\sum_{\mathrm{i}=1}^{\mathrm{n}} \frac{1}{\mathrm{~T}_{\mathrm{a}}}} \\
\mathrm{T}_{\mathrm{B}}=\hat{\mathrm{T}}_{\mathrm{B}} \pm \mathrm{t}\left(\mathrm{m}-2, \frac{\alpha}{2}\right) \\
\operatorname{Var}\left(\mathrm{T}_{\mathrm{B}}\right)
\end{gathered}
$$

where:

$$
\begin{array}{ll}
a_{w} & \text { - water activity in decimal; } \\
R & \text { - universal gas constant equal to } 8.314 \mathrm{~J} \mathrm{~mol}^{-1} \mathrm{~K}^{-1} ; \\
\mathrm{T}_{\mathrm{a}} & \text { - absolute temperature in K; } \\
\Delta \mathrm{h}_{\mathrm{st}} & \text { - isosteric liquid sorption heat in } \mathrm{kJ} \mathrm{kg}^{-1} ; \\
\mathrm{L} & \text { - latent heat of vaporization of free water in } \mathrm{kJ} \mathrm{kg}^{-1} \text {; }
\end{array}
$$


$\mathrm{Q}_{\mathrm{st}} \quad$ - integral isosteric heat of sorption in $\mathrm{kJ} \mathrm{kg}^{-1}$;

$\Delta S \quad$ - entropy differential sorption in $\mathrm{kJ} \mathrm{kg}^{-1} \mathrm{~K}^{-1}$;

$\Delta \mathrm{G}$ - Gibbs free energy in $\mathrm{kJ} \mathrm{kg}^{-1}$;

$\mathrm{T}_{\mathrm{B}} \quad$ - isokinetic temperature in $\mathrm{K}$;

$\mathrm{T}_{\mathrm{hm}}$ - harmonic mean temperature in $\mathrm{K}$;

$\mathrm{n}$ - number of temperatures used; and,

$\mathrm{m}$ - number of enthalpy and entropy data pairs.

\section{Results AND Discussion}

The dependence of the integral isosteric heat of sorption of the damaged beans and evidence of the equilibrium moisture content is shown in Figure 1.

The results show a progressive increase in heat sorption with reduced equilibrium moisture content in all treatment. Bonner \& Kenney (2013) stated that this is because in the initial phase of sorption, there are highly active polar sites on the surface of the product, which are covered by water molecules forming the monolayer. This results in stronger water-solid interactions.

It can be observed that the values of the integral isosteric heat of desorption process of the damaged beans were higher than the values of the integral isosteric heat of adsorption of the damaged beans; however, the values tend to a common equilibrium value at higher moisture contents (Figure 1). This trend indicates that desorption process requires lower energy in order to occur than adsorption process. These results support the findings of Goneli et al. (2010) and Bonner \& Kenney (2013).

Moreover, from Figure 1, it can be observed that the control (undamaged) beans showed higher values of integral isosteric heat of sorption than the damaged beans. The mechanical damage made more sites available for water molecules thereby providing a higher number of connections and consequently reducing the total energy of the phenomenon.

Figure 2 shows the behavior of the differential entropy of sorption of the damaged and the control beans as a function of the equilibrium moisture content.

The differential entropy of sorption showed the same pattern as the integral isosteric heat of sorption. It is known

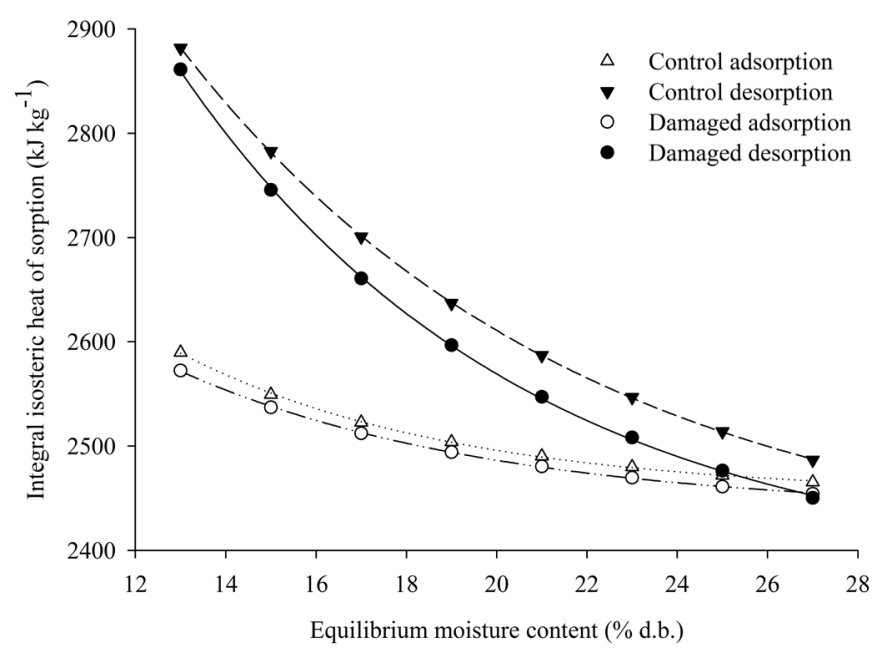

Figure 1. Integral isosteric heat of sorption of the damaged and the control beans as a function of equilibrium moisture content

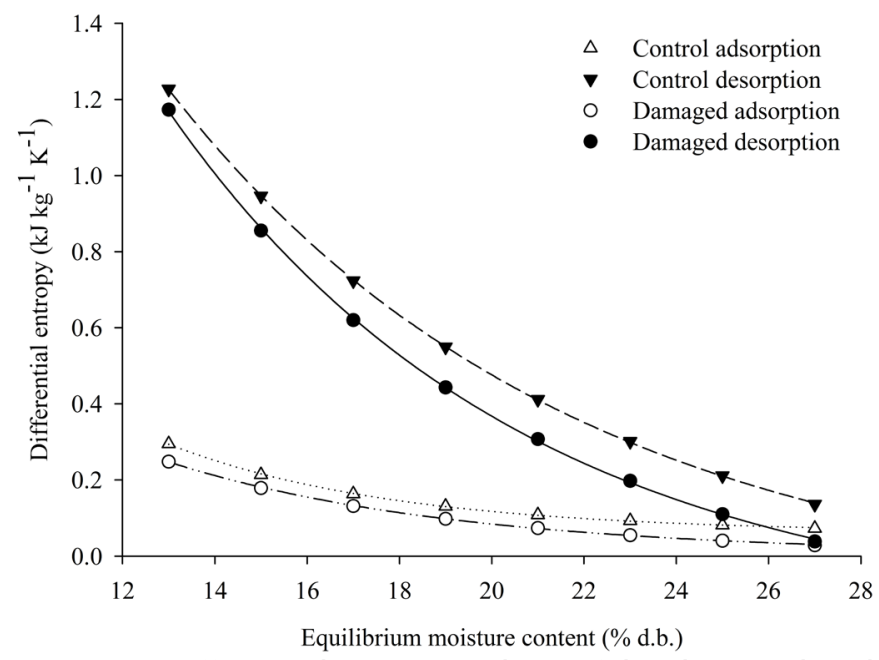

Figure 2. Differential entropy values of the damaged and the control beans as a function of equilibrium moisture content

that the entropy of a material is proportional to the number of sorption sites available at a specific energy level, which gives an indication of the state of mobility of water molecules. Therefore, the water molecules showed increased mobility in the desorption process than in the adsorption process. The same result was reported by Goneli et al. (2010). Moreover, the differential entropy tends to decrease to a constant value at high equilibrium moisture content, indicating that the sorption process may be reversible to some value (Madamba et al., 1996).

The mechanical damage made the differential entropy lower in both sorption processes compared with the control. This trend was expected, as a high number of available sorption sites was confirmed (fissures and cracks).

Table 1 lists the equations fitted to the experimental data of the isosteric heat and the differential entropy of the damaged beans sorption and the control. It can be observed that the equations are suitable to predict the phenomenon as the determination coefficients are greater than 99\% (Table 1).

Figure 3 illustrates the enthalpy-entropy relationship with the water sorption process of the damaged and the control beans.

It was observed that a strong correlation exists between the two thermodynamic properties by the linearity of the lines. However, only the difference between the harmonic mean temperature $\left(\mathrm{T}_{\mathrm{hm}}\right)$ and the isokinetic temperature $\left(\mathrm{T}_{\mathrm{B}}\right)$ may indicate that such relationship exists (enthalpy-entropy compensation theory). $\mathrm{T}_{\mathrm{hm}}$ was $307.59 \mathrm{~K}$ and the $\mathrm{T}_{\mathrm{B}}$ values

Table 1. Equations fitted to the experimental data of the integral isosteric heat and differential entropy of sorption of the damaged and the control beans

\begin{tabular}{|c|c|c|}
\hline Identification & Adjusted equation & $\begin{array}{c}\mathbf{R}^{2} \\
(\%)\end{array}$ \\
\hline Adsorption & $Q_{s t}=2436.9777+871.4348 * \exp \left(0.1437 * U_{e}\right)$ & 0.9996 \\
\hline damaged & $\Delta S=0.0045+1.9276 * \exp \left(0.1594 * U_{e}\right)$ & 0.9996 \\
\hline Adsorption & $Q_{s t}=2453.1063+1165.1188 * \exp \left(0.1653 * U_{e}\right)$ & 0.9997 \\
\hline control & $\Delta S=0.0615+3.2963 * \exp \left(0.2040 * U_{e}\right)$ & 0.9996 \\
\hline Desorption & $Q_{s t}=2374.5345+2643.6283 * \exp \left(0.1305 * U_{e}\right)$ & 0.9998 \\
\hline damaged & $\Delta S=0.1728+7.2625 * \exp \left(0.1299 * U_{e}\right)$ & 0.9998 \\
\hline Desorption & $Q_{s t}=2384.3569+2148.1028 * \exp \left(0.1125 * U_{e}\right)$ & 0.9999 \\
\hline control & $\Delta S=0.1342+6.0285 * \exp \left(0.1145 * U_{e}\right)$ & 0.9999 \\
\hline
\end{tabular}




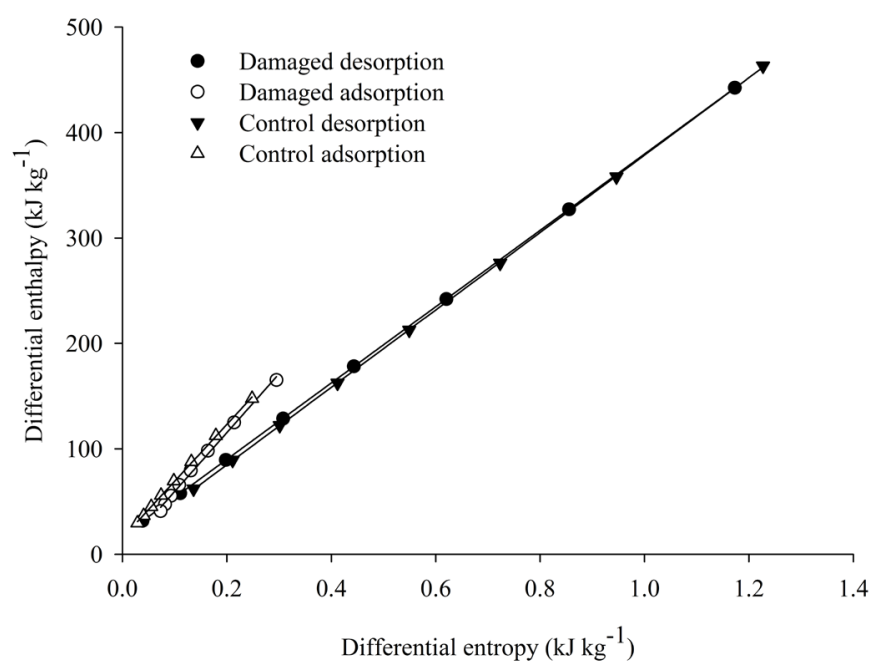

Figure 3. Compensation enthalpy-entropy of the sorption process of the damaged and the control beans

are listed in Table 2, thereby confirming the chemically linear compensation. Furthermore, as $\mathrm{T}_{\mathrm{B}}$ values were higher than $\mathrm{T}_{\mathrm{hm}}$, it can be concluded that the sorption mechanism is controlled by the enthalpy (Corrêa et al., 2012). Previous studies also made the conclusion that sorption was controlled by the enthalpy (Corrêa et al., 2015; Goneli et al., 2013).

Figure 4 shows the Gibbs free energy of the damaged beans and the control beans.

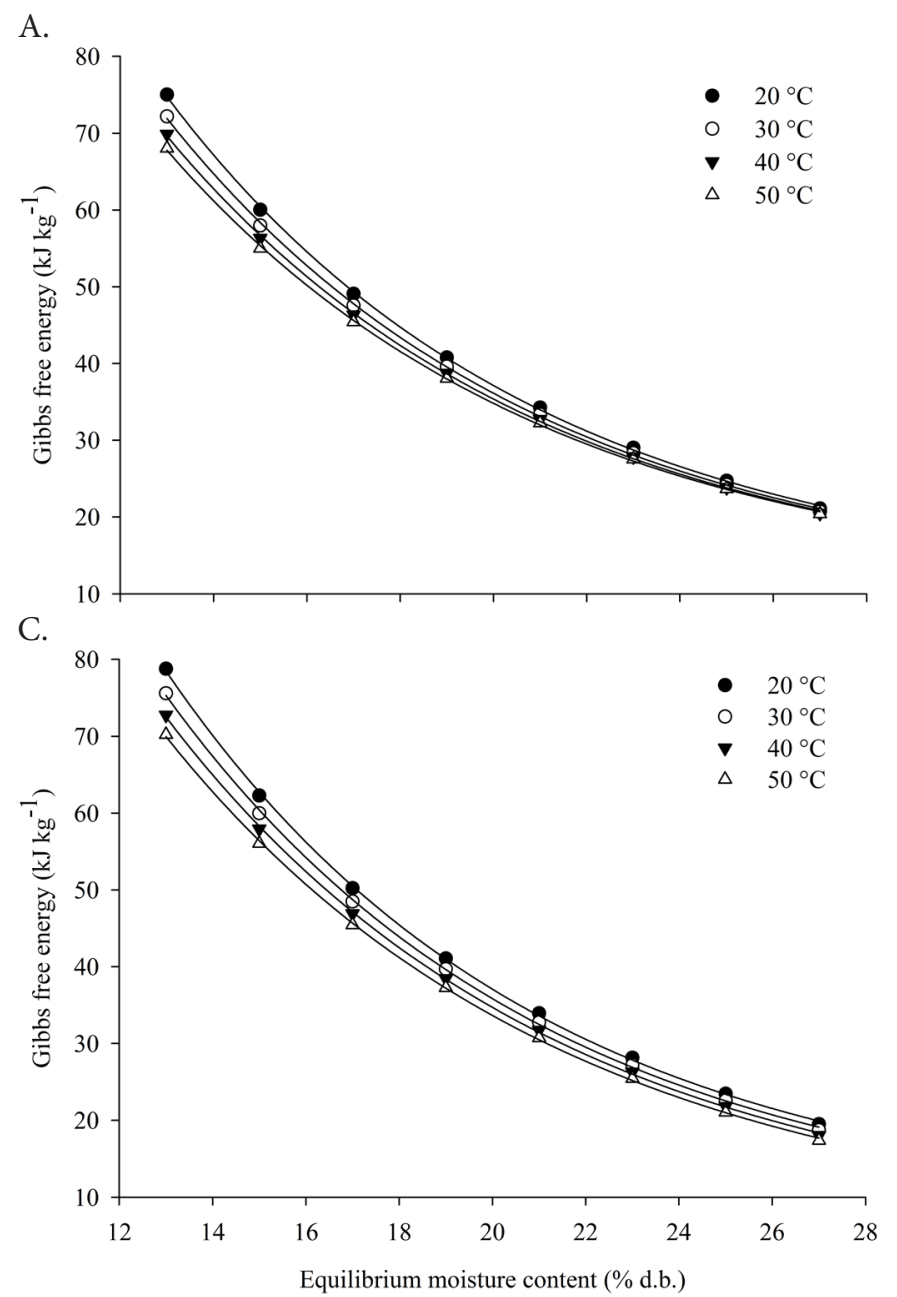

Figure 4. Gibbs free energy of (A) damaged beans adsorption, (D) control desorption
Table 2. Isokinetic temperature and Gibbs free energy at the isokinetic temperature of the damaged beans and the control

\begin{tabular}{lccccc}
\hline \multirow{2}{*}{ Parameters } & \multicolumn{2}{c}{ Adsorption } & & \multicolumn{2}{c}{ Desorption } \\
\cline { 2 - 3 } \cline { 5 - 6 } $\mathrm{T}_{\mathrm{B}}(\mathrm{K})$ & 558.13 & 538.22 & & 362.00 & 367.11 \\
$\Delta \mathrm{G}_{\mathrm{B}}\left(\mathrm{kJ} \mathrm{kg}^{-1}\right)$ & 3.74 & 15.52 & & 17.63 & 11.44 \\
$\mathrm{R}^{2}$ & 0.9962 & 0.9993 & & 0.9999 & 0.9999 \\
\hline
\end{tabular}

The Gibbs free energy is a thermodynamic function that represents the maximum amount of energy released in a process at constant temperature and pressure, which is available to be used. It is the balance between enthalpy and entropy. The effect of a change in water sorption in Gibbs free energy is generally accompanied by changes in enthalpy and entropy (Telis-Romero et al., 2005). Gibbs free energy decreased with increase in temperature and equilibrium moisture content, and in the latter case, it tends to a constant value. This behavior was also observed in previous studies by Sousa et al. (2015), Oliveira et al. (2014), and Kaleemullah \& Kailappan (2007).

From Figure 4, it can be observed that the Gibbs free energy in the desorption process was higher compared to the adsorption process at temperatures of 20,30 , and $40^{\circ} \mathrm{C}$, similar to results obtained by Kaleemullah \& Kailappan (2007). For a temperature of $50{ }^{\circ} \mathrm{C}$, the results obtained for the control beans were similar as shown in Figures $4 \mathrm{C}$ and 4D. This trend

B.

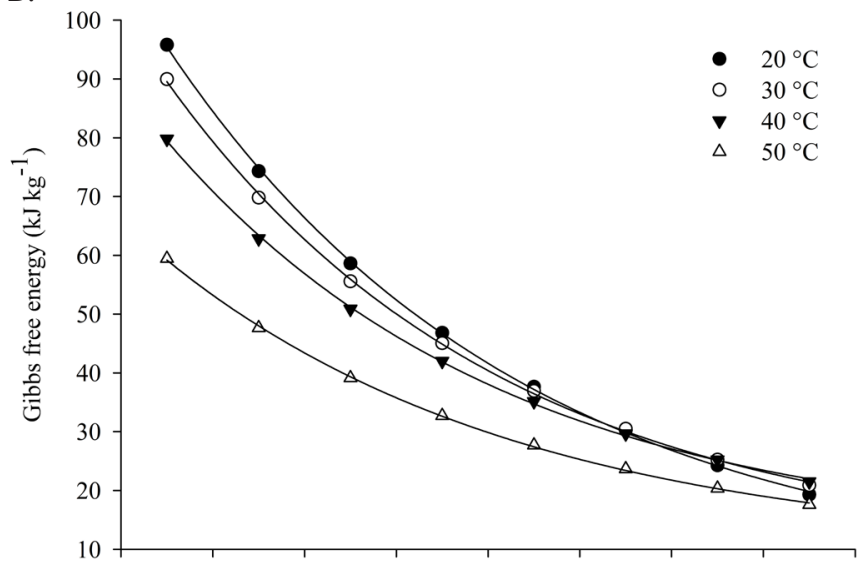

D.

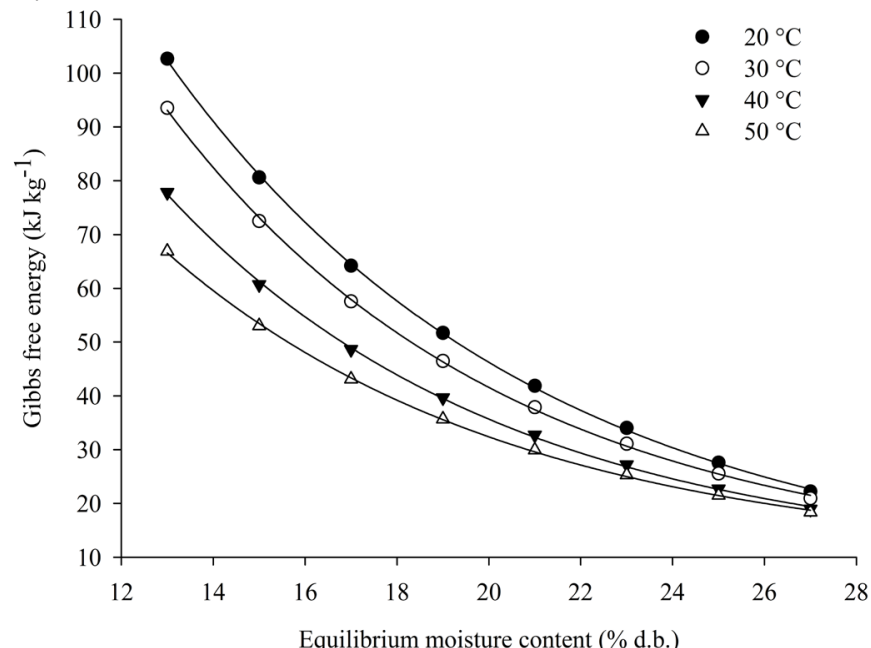

(B) damaged beans desorption (C) control adsorption, 
indicates that damage effect plays a higher role in terms of energy than temperature for sorption processes below 50 ${ }^{\circ} \mathrm{C}$. Moreover, positive values of Gibbs free energy indicate endothermic reactions; in other words, these reactions will happen only with energy input (i.e., from the environment).

\section{Conclusions}

1. Mechanical damage has considerable effect on the thermodynamic properties of bean sorption process.

2. The energy required for desorption, represented by isosteric heat, was lower for the damaged grains. For the adsorption process, the isosteric heat showed lower demand for energy in the damaged grains compared with the control grains.

3. A higher number of available sites of sorption in the damaged grains was confirmed, making adsorption difficult and desorption easy.

4. Exponential models were fitted to the integral isosteric heat data and the differential entropy of sorption as a function of the equilibrium moisture. The models showed high values of the determination coefficient $\left(\mathrm{R}^{2}>0.9996\right)$.

5. Compensation enthalpy-entropy theory was confirmed and it can be concluded that the sorption mechanism for the damaged grains and the control grains is controlled by enthalpy.

\section{ACKNOWLEDGEMENTS}

The authors wish to thank Fundação de Amparo à Pesquisa do Estado de Minas Gerais (FAPEMIG) and the Instituto Federal de Educação, Ciência e Tecnologia do Sudeste de Minas Gerais (IF Sudeste MG) for their financial support.

\section{Literature Cited}

Angelovič, M.; Fiantoková, S.; Angelovič, M. Effect of manipulation technique on the grains quality in post-harvesting lines. Animal Science and Biotechnologies, v.46, p.431-436, 2013.

Ascheri, D. P. R.; Bastos, S. M. C. Propiedades de adsorción de agua de dos genotipos de arroz rojo. Engenharia Agrícola, v.35, p.134-143, 2015. https://doi.org/10.1590/1809-4430-Eng.Agric. v35n1p134-143/2015

Baptestini, F. M.; Corrêa, P. C.; Vanegas, J. D. B.; Leite, R.; Botelho, F. M.; Campos, R. C. Water sorption kinetics of damaged beans: GAB model. Revista Brasileira de Engenharia Agrícola e Ambiental, v.21, p.550-555, 2017. http://dx.doi.org/10.1590/1807-1929/ agriambi.v21n8p550-555

Bonner, I. J.; Kenney, K. L. Moisture sorption characteristics and modeling of energy sorghum (Sorghum bicolor (L) Moench). Journal of Stored Products Research, v.52, p.128-136, 2013. https:// doi.org/10.1016/j.jspr.2012.11.002

Brasil. Ministério da Agricultura e Reforma Agrária. Secretaria Nacional de Defesa Agropecuária. Regras para análise de sementes. Brasília: MARA, 2009. 395p.

Corrêa, P. C.; Oliveira, G. H. H. de; Santos, E. de S. Thermodynamic properties of agricultural products processes. In: Arana, I. (ed.) Physical properties of foods: Novel measurement techniques and applications. Boca Raton: CRC Press, 2012. Cap.6. p.131-141.
Corrêa, P. C.; Reis, M. F. T.; Oliveira, G. H. H. de; Oliveira, A. P. L. R. de; Botelho, F. M. Moisture desorption isotherms of cucumber seeds: Modeling and thermodynamic properties. Journal of Seed Science, v.37, p.218-225, 2015. https://doi.org/10.1590/2317$1545 \mathrm{v} 37 \mathrm{n} 3149549$

Goneli, A. L. D.; Corrêa, P. C.; Oliveira, G. H. H. de; Afonso Junior, P. C. Water sorption properties of coffee fruits, pulped and green coffee. Lebensmittel-Wissenschaft Technologie-Food Science and Technology, v.50, p.386-391, 2013. https://doi.org/10.1016/j. lwt.2012.09.006

Goneli, A. L. D.; Corrêa, P. C.; Oliveira, G. H. H. de; Gomes, C. F.; Botelho, F. M. Water sorption isotherms and thermodynamic properties of pearl millet grain. International Journal of Food Science \& Technology, v.45, p.828-838, 2010. https://doi. org/10.1111/j.1365-2621.2010.02208.x

Kaleemullah, S.; Kailappan, R. Monolayer moisture, free energy change and fractionation of bound water of red chillies. Journal of Stored Products Research, v.43, p.104-110, 2007. https://doi. org/10.1016/j.jspr.2005.12.001

Machado, C. M.; Ferruzzi, M. G.; Nielsen, S. S.; Impact of the hardto-cook phenomenon on phenolic antioxidants in dry beans (Phaseolus vulgaris). Journal of Agricultural and Food Chemistry, v.56, p.3102-3110, 2008. https://doi.org/10.1021/jf072861y

Madamba, P. S.; Driscoll, R. H.; Buckle, K. A. Enthalpy-entropy compensation models for sorption and browning of garlic. Journal of Food Engineering, v.28, p.109-119, 1996. https://doi. org/10.1016/0260-8774(94)00072-7

Maquet, A.; de Ron, A. M.; Baudoin, J. P. Editorial: Improvement of sustainable Phaseolus produttion in Europe for human consumption-PHASELIEU. Biotechnological Agronomic Society Environmental, v.3, p.195-196, 1999.

Mesquita, F. R.; Corrêa, A. D.; Abreu, C. M. de; Lima, R. Z. A.; Abreu, A. de F. B. Linhagens de feijão (Phaseolus vulgaris L.): Composição química e digestibilidade de proteína. Ciência e Agroecologia, v.31, p.1114-1121, 2007. https://doi.org/10.1590/ S1413-70542007000400026

Moreira, R.; Chenlo, F.; Torres, M. D.; Vallejo, N. Thermodynamic analysis of experimental sorption isotherms of loquat and quince fruits. Journal of Food Engineering, v.88, p.514-521, 2008. https:// doi.org/10.1016/j.jfoodeng.2008.03.011

Oliveira, D. E. C. de; Resende, O.; Chaves, T. H.; Souza, K. A.; Smaniotto, T. A. de S. Propriedades termodinâmicas das sementes de pinhão-manso. Bioscience Journal, v.30, p.147-157, 2014.

Oliveira, G. H. H. de; Corrêa, P. C.; Santos, E. de S.; Treto, P. C.; Diniz, M. D. M. S. Evaluation of thermodynamic properties using GAB model to describe the desorption process of cocoa beans. International Journal of Food Science \& Technology, v.46, p.20772084, 2011. https://doi.org/10.1111/j.1365-2621.2011.02719.x

Santos, J. F. dos; Alvarenga, R. O.; Timóteo, T. S.; Conforto, E. de C.; Marcos Filho, J.; Vieira, R. D. Avaliação do potencial fisiológico de lotes de sementes de soja. Revista Brasileira de Sementes, v.33, p.743-751, 2011. https://doi.org/10.1590/S010131222011000400016

Sousa, K. A. de; Resende, O.; Goneli, A. L. D.; Smaniotto, T. A. de S.; Oliveira, D. E. C. de. Thermodynamic properties of water desorption of forage turnip seeds. Acta Scientiarium. Agronomy, v.37, p.11-19, 2015. https://doi.org/10.4025/actasciagron. v37i1.19333 
Telis-Romero, J.; Kohayakawa, M. N.; Silveira Júnior, V.; Pedro, M. A. M.; Gabas, A. L. Enthalpy-entropy compensation based on isotherms of mango. Ciência e Tecnologia de Alimentos, v.25, p.297-303, 2005. https://doi.org/10.1590/S010120612005000200020
Thys, R. C. S.; Noreña, C. P. Z.; Marczak, L. D. F.; Aires, A. G.; Cladera-Oliveira, F. Adsorption isotherms of pinhão (Araucaria angustifolia seeds) starch and thermodynamic analysis. Journal of Food Engineering, v.100, p.468-473, 2010. https://doi. org/10.1016/j.jfoodeng.2010.04.033 